Ross, R. J. Jr. 1951: Stratigraphy of the Garden City Formation in Northeastern Utah, and its trilobite faunas. Bull Peabody Mus. nat. Hist. 6, 161 pp.

Troelsen, J. C. 1950: Contributions to the geology of northwest Greenland, Ellesmere Island and Axel Heiberg Island. Meddr Grønland 149, 7, 85 pp.

\title{
1:500 000 mapping of the Thule district, North-West Greenland
}

\author{
Peter R. Dawes
}

Field investigations aimed at the production of a 1:500 000 map sheet of the Thule district were continued during August and early September. The unusually poor weather conditions and the premature arrival of the winter's snowfall, reduced the season to some 20 effective working days.

The field work was in two parts. At the beginning of the season a Jet Ranger helicopter was chartered at Thule Air Base and four days were spent investigating nunatak and inland areas north of Savigsivik and Kap York and at the heads of Wolstenholme Fjord, Olrik Fjord and Inglefield Bredning. The second part was an investigation of the Proterozoic Thule Group on Herbert $\varnothing$, Northumberland $\varnothing$ and Hakluyt $\varnothing$. Transport for this phase was a locally hired boat from Avatak Henson of Moriussaq.

Certain logistic support was supplied to $H$. R. Cooke who visited the Thule district at the end of the field season to assess the economic potential of various mineral localities. Kurt Thomsen ably assisted both in Cooke's and the author's field programmes.

\section{Crystalline basement}

The main rock types and the chronological development of the Precambrian basement in the Thule district have been reported in earlier accounts (Dawes, 1972, 1975). Notes on the new mapping follow.

\section{Kap York - Savigsivik region}

In this region the Inland Ice reaches the sea as numerous wide productive glaciers restricting the ice-free areas to islands, nunataks and isolated peninsulas. De DødesFjord and Sidebriksfjord are generally inaccessible by boat. Previous reference to the geology has been restricted to mention of Archaean gneiss and granite (Chamberlin, 1895; Koch, 1920) and the meteoritic and other iron occurrences in the Savigsivik area (Peary, 1898; Bøggild, 1953).

The crystalline basement is composed of a variety of highly deformed gneisses, schists, amphibolites and supracrustal rocks, that are cut by a suite of igneous rocks (Kap York meta-igneous complex) and by still younger late Proterozoic dolerite dykes. Grey weather- 


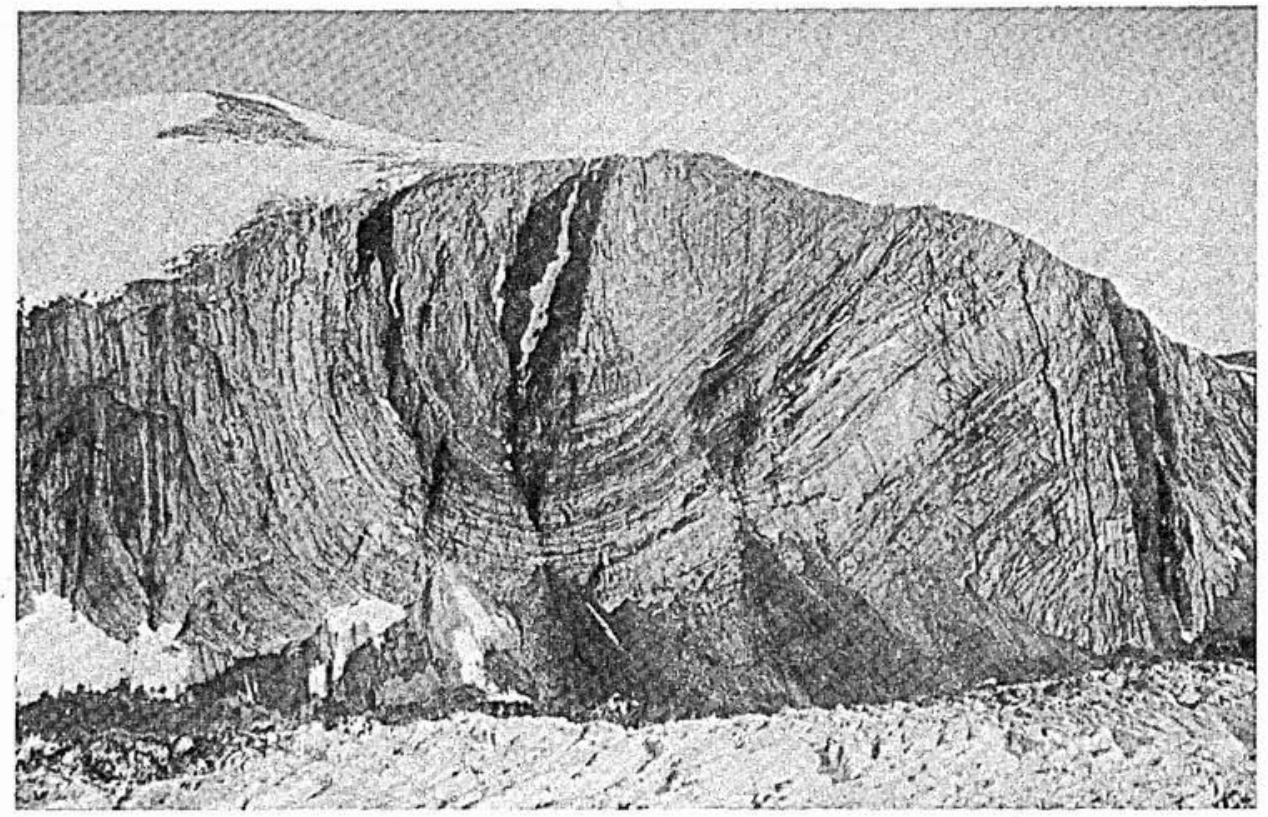

Fig. 7. A prominent synform involving amphibolitic supracrustal rocks and underlying gneisses in the relatively little known Melville Bugt region. Nunatak at the head of Sidebriksfjord. Height of the cliff above the glacier is about $450 \mathrm{~m}$.

ing granodioritic gneisses form the majority of the terrain. These are mainly of streaky to veined type showing frequent transitions to homogeneous gneiss and granite sensu lato. Biotite and lesser amounts of hornblende are the main mafic minerals. North of Savigsivik, on the west side of Meteorbugt, the gneisses are leucocratic and have only weak foliation.

Amphibolite and associated ultramafic rocks occur throughout much of the gneiss terrain as small lenses and schlieren. However, on the nunataks at the head of Sidebriksfjord amphibole-rich rocks form thick mappable units having conformable contact relationship with underlying gneisses (fig. 7). Rock types vary from hornblende schist to banded amphibolite and hornblendite. Biotite schists and chlorite-talc schists are common associates.

Metasedimentary supracrustal rocks occur in De Dødes Fjord. Here tracts of brown to rusty weathering biotite schists, chlorite schists and iron-rich schists and gneiss (see below) occur in association with pink to white psammitic rocks. Although intensely folded together on a small-scale the psammitic rocks structurally overlie the gneisses and schists on a regional scale - a relationship that is seen on several nunataks at the head of the fjord. A typical sequence has shallow dipping, brown weathering, biotite schists and gneiss at the base, passing upwards into rusty weathering gneiss and schists in which magnetite and haematite are abundant 'either disseminated or as patches, thin layers or bands. There seems to be a gradation from these rocks into the overlying psammitic sequence which in the lower part contains iron and is composed of quartzitic schists, quartz-rich gneiss and banded quartzite. The upper part of the psammitic sequence contains medium-grained, more massive quartzites which may display a mafic foliation. 
The northern contact of the Kap York meta-igneous complex with the gneisses, schists and psammitic rocks to the north is ice-covered in the De Dødes Fjord region. The nunataks on the northern side of the Kap York peninsula are composed of light coloured, medium to coarse grained, often equigranular, intermediate to acid intrusives in which pyroxene, amphibole and biotite are the mafic minerals. The nunatak distribution shows the boundary of the complex to have a general NW trend towards Parker Snow Bugt. The sharp intrusive contact with older gneisses noted by Davies et al. (1963) to the south-east of Parker Snow Bugt is presumably the only exposed contact of the complex.

All the rocks described above are cut by a swarm of WNW to NW trending unmetamorphosed dolerite dykes as well as a few NNE trending dykes. The WNW dykes are almost certainly the eastern extension of the swarm that post-dates the Thule Group in the North Star Bugt area (Davies et al., 1963).

\section{Structure, age and relationships}

Where exposed together, gneisses generally structurally underlie both amphibolite and supracrustal successions. However, contacts are concordant and it is not known if the gneisses (or part of them) represent an older basement to amphibolites (of possible igneous origin), and/or the pelitic and psammitic sediments. Both gneisses and 'cover' rocks have been deformed and folded together by at least two important deformation phases. Isoclinal folds occur in the gneisses and overlying rocks, and the amphibolites, at least, have been affected by important NW folding.

The Kap York meta-igneous complex post-dates the main deformation and metamorphism of the North Star Bugt area (Dawes, 1975). However, regional deformation, metamorphism and feldspathisation have affected the complex producing foliated, porphyroblastic and schistose fabrics. It is possible that some gneisses in the Melville Bugt region have been derived from igneous rocks of the same age as those of the Kap York complex. The leucocratic gneisses in the Meteorbugt area should be investigated with this in view.

\section{Wolstenholme Fjord - Inglefield Bredning region}

The nunatak and inland areas between the heads of these fjords $\left(c .1500 \mathrm{~km}^{2}\right)$ are composed of brown, reddish brown and grey weathering, granodioritic, biotite and hornblende bearing, veined to streaky gneisses. Much ground moraine covers the prominent plateau surface and exposures over much of the area are restricted to fjord and valley walls. Amphibolotic material is common as thin layers and lenses and in places forms a banded gneiss. Apart from a few, more continuous, amphibolite bands, and some layers of biotite and chlorite schists, no structural markers exist and the gneisses show little lithological variation apart from transitions to porphyroblastic and foliated granitic rocks. A few small areas of ?post-tectonic biotite granite occur.

In the north, on Harward Øer, the gneisses and assosiated amphibolites are cut by a series of deformed pink granite sheets. Further to the north the basement shows a wide variety of rock types and biotite-garnet schists, anorthosite and psammitic and amphibolitic supracrustal rocks occur as mappable units (Dawes, 1972). 


\section{Thule Group}

The Thule Group of middle to late Proterozoic age is composed of unmetamorphosed sedimentary and igneous rocks overlying the Precambrian basement with profound unconformity.

\section{Kap York - Inglefield Bredning region}

During helicopter traverses of the inland area a number of new occurrences of the Thule Group were located. The largest is a group of exposures, partially ice covered, on the land between De Dødes Fjord and Sidebriksfjord, north-west of Savigsivik. Here, red and pink sandstone, grit and quartz-pebble conglomerate overlie the gneisses with shallow angular unconformity. The sediments form a small isolated basin $\left(c .60 \mathrm{~km}^{2}\right)$ separated from the Thule Basin to the west by high altitude gneiss and schist terrain.

Other outcrops of red and pink sandstone with conglomerate (in total c. $15 \mathrm{~km}^{2}$ ) were discovered on Nunararssuaq at the head of Inglefield Bredning. These rocks form a thin cover on the basement peneplain and undoubtedly once formed continuous outcrops with the main Thule Group exposures to the west.

\section{Herbert $\varnothing$, Northumberland $\varnothing$ and Hakluyt $\varnothing$}

The basal strata of the Thule Group - the Wolstenholme Formation - reach their thickest development on these islands. The rocks are shallow water, multicoloured clastic sediments with volcanic and intrusive rock units. Six mappable units can be recognised in the $2000 \mathrm{~m}$ succession (fig. 8) of which units 1, 2 and 3 constitute the 'basal multicoloured member' described earlier (Dawes, 1975). Volcanic rocks, not hitherto located in situ, were found to make up a thick unit near the base of the succession (unit 2).

The Precambrian basement is exposed in north-western Northumberland $\emptyset$. Unit 1 directly overlying this is composed of medium-grained, light weathering, buff, red, purple and brown sandstones; unit 3 is thinner bedded and composed of red, green and buff shales and fine-grained sandstones with some dolomite beds at the base. At some localities a thin fine-grained stromatolitic dolomite forms the basal bed. Units 1 and 3 both vary in thickness.

Unit 2 is dark coloured and contains both recessive and resistent layers. It is composed of brown to tan coloured bedded tuffs, brown, purple and dark grey agglomerates and volcanic breccias of rubbly appearance, and more resistent sill-like andesitic or basaltic layers, examples of which limit the top and base of the unit. The agglomerates are generally composed of angular to sub-rounded grey to purple volcanic blocks but in places quartzite and chert blocks occur. Calcite veining is common. The ratio of blocks to matrix varies considerably in different parts of the section. The tuffs are usually well bedded and in places are pisolitic, with pisolites up to $1 \mathrm{~cm}$ across. The resistent layers are composed of green to dark grey andesite or basalt in which columnar jointing is common. Calcite and agate amygdales characterise the top few metres of some layers. Red to brown agates over $10 \mathrm{~cm}$ in diameter are present in some agglomerate layers. The stratigraphic status of all the resistent sill-like layers is not known and some may be intrusive rather than extrusive.

Units 4,5 and 6 are all of characteristic colour and lithology. Unit 4 is composed of thick 


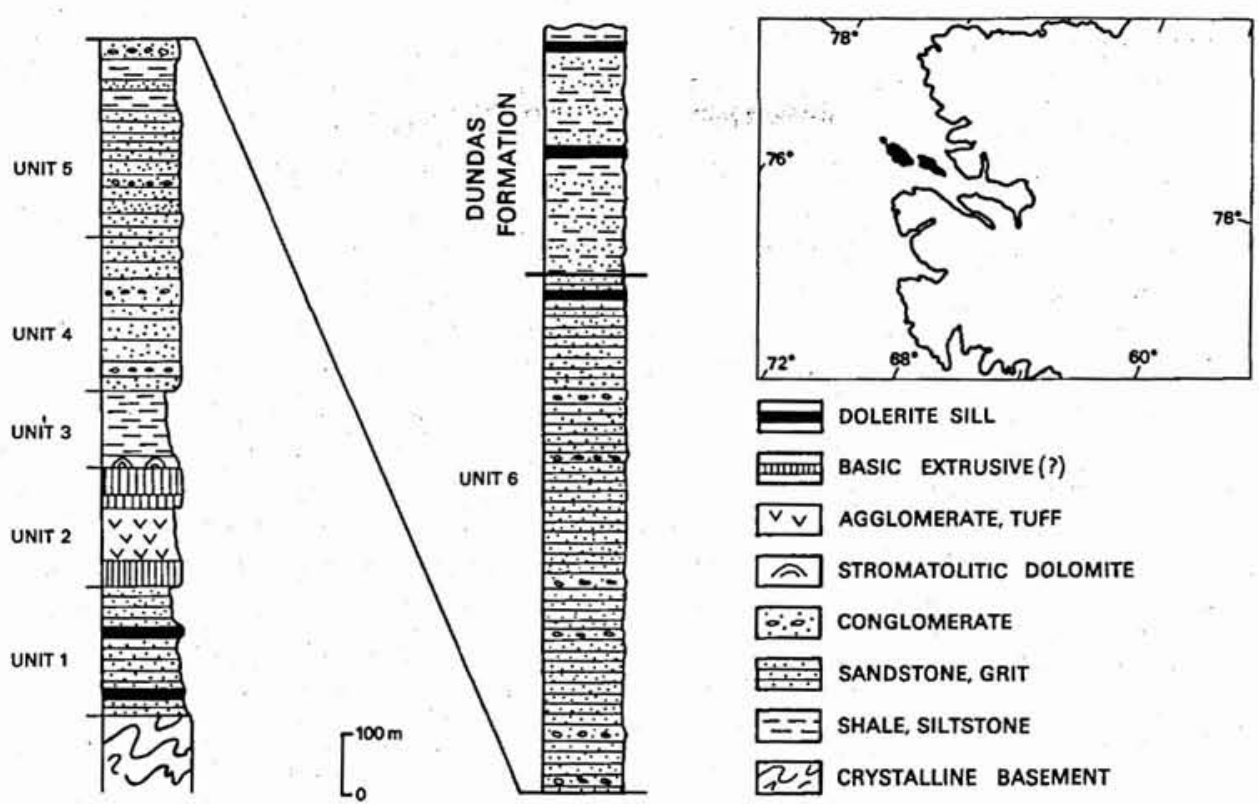

Fig. 8. Simplified geological section of the basal part of the Proterozoic Thule Group (Wolstenholme Formation) on Herbert $\emptyset$, Northumberland $\emptyset$ and Hakluyt $\emptyset$. These islands are shown in black on the inset map.

bedded, white, almost pure sandstones; unit 5 is red coloured composed of various ferruginous sandstones with green and grey shales in the upper part; while unit 6 is a monotonous sequence of thin to medium bedded, buff to yellow weathering sandstones. Sporadically scattered quartz pebbles in sandstone and discrete quartz-pebble conglomerate incursions occur in all three units.

\section{Regional correlation}

The Thule Group was laid down in a slowly subsiding depression - the Thule Basin - that now forms part of the stable platform block south of the Franklinian geosyncline. Christie (1972) has likened certain Precambrian beds on the outer coast of south-eastern Ellesmere Island to the Thule Group and has included them in the Thule Basin. The volcanic suite discovered on Northumberland $\emptyset$ is strikingly similar to, and has the same associated sedimentary rock types as, those described by Christie from Ellesmere Island. This furnishes a direct correlation of the sequences across Smith Sound and is a significant step in the evaluation of the sedimentary and tectonic history of the northern Baffin Bay-Smith Sound region.

\section{Economic geology}

The black ilmenite-rich sands present on parts of the coast in southern Steensby Land to as far south as North Star Bugt $\left(76^{\circ} 30^{\prime} \mathrm{N}\right)$ (Ghisler \& Thomsen, 1971; Dawes, 1975) were 
noted, albeit in lesser quantities, as far north as Siorapaluk in Robertson Fjord $\left(77^{\circ} 45^{\prime} \mathrm{N}\right)$. Sampling was carried out at several localities by H. R. Cooke and Kurt Thomsen.

The discovery of magnetite-rich rocks, in places with haematite and sulphides in a metasedimentary sequence in De Dødes Fjord is significant. Some of the rocks resemble classical banded ironstones composed of alternating and regular bands of magnetite and quartz. The magnetite bands reach several millimetres wide and can form over 50 per cent of the rock. More commonly the magnetite occurs irregularly in gneisses and schists but in many places nearly pure magnetite rock occurs. At other localities near the Inland Ice south of Thule Air Base iron-rich gneiss and schist occur as several tracts in association with amphibolites and basic schists.

The iron-rich rocks form a regional belt traceable for over $80 \mathrm{~km}$ from Wolstenholme $\varnothing$ and Magnetitbugt in the west across the mainland and into the De Dødes Fjord region. The thickness of the occurrence varies along the strike but it clearly contains appreciable amounts of iron ore. On Wolstenholme $\emptyset$ and on the mainland to the east the occurrence is 15 m thick (Davies et al., 1963) while in the De Dødes Fjord region the total thickness of iron-rich rocks probably exceeds $40 \mathrm{~m}$. How far eastwards the iron belt continues into the comparatively unexplored Melville Bugt region remains unknown but it is of some interest that Bøggild (1953) mentions the presence of large masses of haematite-magnetite(-quartz) ore from Bushnan $\varnothing$ some $60 \mathrm{~km}$ to the south-east of De Dødes Fjord.

\section{References}

Bøggild, O. B. 1953: The mineralogy of Greenland. Meddr Grønland 149,3, 442 pp.

Chamberlin, T. C. 1895: Geology . Appendix A.In Bryant, H. C., The Peary Auxiliary Expedition of 1894. Bull. geogr. Club Philadelphia 1,(5), 167-194.

Christie, R. L. 1972: Central Stable Region. In Christie, R. L. et al., The Canadian Arctic Islands and the Mackenzie region. 25 Congr. geol. int. Canada. Guidebook field excursion A66, 40-87.

Davies, W. E., Krinsley, D. B. \& Nicol, A. H. 1963: Geology of the North Star Bugt area, Northwest Greenland. Meddr Grønland 162,12, 68 pp.

Dawes, P. R. 1972: Precambrian crystalline rocks and younger sediments of the Thule district, North Greenland. Rapp. Grønlands geol. Unders. 45, 10-15.

Dawes, P. R. 1975: Reconnaissance of the Thule Group and the underlying basement rocks between Inglefield Bredning and Melville Bugt, North Greenland. Rapp. Gronlands geol. Unders. 75, 34-38.

Ghisler, M. \& Thomsen, B. 1971: The possibility of ilmenite placers in the Thule district, North Greenland. Rapp. Grønlands geol. Unders. 43, 15 pp.

Koch, L. 1920: Stratigraphy of Northwest Greenland. Meddr dansk geol. Foren. 5,17, 78 pp.

Peary, R. E. 1898: Northward over the "Great Ice". 2, 618 pp. New York: Frederick A. Stokes. 